\title{
THE LIQUIDATOR LIABILITY IN THE PROCESS OF CORPORATE LIQUIDATION
}

\author{
Agus Nurudin \\ Practitioner and Lecturer at Faculty of Law, Tujuh Belas Agustus University \\ ags_nurudin@yahoo.com
}

\begin{abstract}
Provisions of Article 149 paragraph (1) of Law Number 40 of 2007ConcerningLimited Liability Company do not mention the authority to verify the bill of creditors and the authority to sell property assets. In practice, the liquidator often acts as the seller of the company's assets. This was done to fill the legal vacuum for the smooth liability of the liquidator. Therefore, the problem is how are the provisions of the legislation to the obligations of the liquidator in the process of liquidation of the limited liability company? The study approach method used is a description of the juridical critical analysis. The urgency of writing this article is so that the liquidator is authorized to verify creditor bills and authority and sell assets. The result of a descriptive study of critical analysis is normal obligations of the liquidator to do the liquidation of the company's assets other than those stipulated in article 149 paragraph (1) namely the authority to verify the creditor's bill as well as the authority to sell Limited Liability Company assets.
\end{abstract}

Keywords: Liability Liquidator; Liquidation; Limited Liability Company

\section{Introduction}

A company that is declared as insolvent would lose the propriety right to its assets due to the court's bankruptcy order which mandates a third party to manage the assets in order to resolve the corporate's liabilities. Therefore, the rights and responsibilities of the insolvent corporate, or debtor, over assets are transferred to this third party called as curator. Every entitlement of the debtor that is issued after the bankruptcydeclaration would not be paid or solved by the assetsunless if such entitlement is able to pay off the liabilities. ${ }^{1}$ Thus, the debtor is still able to impose certain measures over the wealth insofar as that helps the bankruptcy resolution.

After the bankruptcy is resolved, the dissolution of a company depends on the court order if requested. In the Indonesia legal system, the dissolution of a company is stipulated in the Law No. 40 of 2007 on Limited Liability Company, Company Act, whereas the Law No. 37 of 2004 on Bankruptcy -or Bankruptcy Act- only stipulates the asset liquidation of an insolvent corporate. Article 142 paragraph (1) of the Limited Company Act stipulates that the dissolution of a company shall be issued when the commerce court had revoked the bankruptcy status of a company due to the insufficiency of assets to settle all of the liabilities. Regardless of that, it is

${ }^{1}$ Rahayu Hartini, 2013, Hukum Kepailitan, Bayu Media, Malang. 
certain that bankruptcy would not concomitantly lead to the dissolution of a company insofar as there is leftover wealth sufficient enough in order to run the company steadily.

In the dissolution process of a company, a liquidation process of the company's assets must be resolved first and foremost. This process is managed by a curator for legal settlement according to bankruptcy law or a liquidator for non-legal (arbitrary) bankruptcy settlement. ${ }^{2}$ In this state, the company (management and owner) cannot pursue or propose any legal action unless such is needed in order to resolve any internal corporate dispute that is related to the liquidation. After all, the dissolution of a company does not strip its legal entitlements until the liquidation process is finished, reported, and approved by either the shareholder(s) or the court.

A corporate liquidation is led by single or multiple liquidators. A liquidator is usually a third party individual or team that is appointed by the shareholder. Otherwise, the head of the directors' board, the chief executive officer (CEO) or the chairman, will be appointed as the liquidator instead. A liquidator is usually given an authority to form a team of consultants, lobbyists, attorneys, mediators, etc in order to help the liquidation process. Article 149 of the Limited Company Act stipulates that the liquidation process consists of 1) documentation and collection of the company's wealth (capitals and liabilities); 2) A public statement in a newspaper or the Official Gazette of the Republic of Indonesia as to the distribution of liquidated assets; 3) Liability settlements to creditors; 4) Distribution of the leftover wealth to shareholders, and; 5) other measures needed as to liability settlement.

In the liquidation process, the liquidator will initiate an open sale of the company's assets, the procedure of which, however, is not regulated by law. The absence of a formal legal procedure to the asset's selling leaves the liquidator vulnerable to a lawsuit from the company under the allegations of misconduct, abuse of power, or even deception. However, there is no regulation or universally accepted categorization which determines whether such liquidator's action is misconduct or not. Therefore, such allegation, or even lawsuit, could lead to an unfair misjudge toward the liquidator, thus leaving him or her without legal standing to counter.

Based on the aforementioned background, the problem which will be scrutinized in this article is focused on the regulation regarding liquidator's responsibilities and code of conduct in a

\footnotetext{
${ }^{2}$ Munir Fuady, 2012, Hukum Pailit, Citra Aditya Bakti, Bandung.
} 
corporate liquidation process. Such a problem will be analyzed through the normative legal approach which only focuses on the formulation of available regulations upon such case.

\section{Result and Discussion}

\subsection{Definition of Bankruptcy, Liquidator, and Corporate Liquidation}

According to Subekti and Tjitrosubidio, the bankruptcy is a condition whereby a debtor definitively fails to pay off his/her liabilities (Subekti \& Tjitrosubidio, 2009: 89). According to the article 1 point 1 of the Bankruptcy Act, the bankruptcy means a general seizure over the whole wealth of an insolvent debtor by a court-ordered curator to manage insolvent settlements. Therefore, bankruptcy is a failure of the debtor to pay off his/her overdueliabilities as determined by the creditor and the court.

Meanwhile, article 2 paragraph 1 of the Bankruptcy Act stipulates that there are requirements to be fulfilled by a debtor in order to propose bankruptcy. First, a debtor must have two or more creditors to whom the debtor fails to pay off at least one overdue and billable debt. Bankruptcy could be proposed by either the debtor or the creditor(s). Moreover, the aforementioned article elucidates the substantive elements which determine a condition of bankruptcy: 1) an overdue and billable debt; 2) a creditor; 3) a debtor, and; 4) the debtor's failure to pay.

Principally, the purposes of bankruptcy law in Indonesia are: 1) guaranteeing an even distribution of debtor's wealth to his/her creditors; 2) preventing the debtor from taking actions which are against, or harmful, to the creditor's interests, and 3) protecting a good-willed debtor to pursue debt relief from the creditor's abuse. However, the law allows the creditor to not only propose bankruptcy of a company, but also its dissolution to the court. If the court approved and declared a company to be dissolved, liquidation of its assets will soon take follow in order to assure the creditor's right to the settlement which is paid through the liquidation's outcome. Therefore, the dissolution of a company and the liquidation of the company's assets are inseparable processes. Regardless, the company still retain its legal status for the sake of an expeditious execution of the company's asset liquidation. Yet, the company cannot enact or initiate any legal action unless if it is needed for the liquidation settlement.

As aforementioned, corporate liquidation is an inseparable measure within corporate dissolution process. If the shareholders initiated the dissolution because of the designated expiration date of the company, as determined by the company's constitution, or a revocation 
order of the court over company's bankruptcy, thus the liquidator is the only party authorized for conducting liquidation. Whereas the liquidation of insolvent company assets will be conducted by a curator. Therefore, the liquidator is only authorized for a liquidation in which the company could retain its debt solvency, hence the revocation court order. Whereas the curator is only authorized by the court for a condition of bankruptcy in which the company assets are not sufficient to pay off all of its debt to the creditors.

Liquidation (vereffening, winding-up) also means settlement and termination of company affairs after being declared by either the shareholders' consensus or the court order to dissolve the company. The article 143 paragraph (2) of Limited Company Act stipulates that a company will be put in a status "under liquidation" if such is undergoing bankruptcy and incoming dissolution. The title "under liquidation" must be added before the company's name in any of its outgoing mail or document. ${ }^{3}$

However, the article 143 paragraph (1) of the Limited Company Act differentiates the definition of 'liquidation' and 'dissolution' of a company. Dissolution is a process towards liquidation which is executed by a liquidator. Although this provision does not explain further about the procedure of liquidation, the Limited Company Act has sufficiently defined the causes and requirements on executing asset liquidation, company dissolution, and settlement which are stipulated throughout the article 142 to 152 .

As a matter of fact, a condition of company liquidation is pretty indistinctive to bankruptcy. As aforementioned, bankruptcy is a condition whereby the debtor is unable to fully pay off his/her liabilities under which the creditor is able to propose bankruptcy to the court. ${ }^{4}$ First, sometimes bankruptcy is used as a method to advertently liquidate a company even though the company is not necessarily insolvent. This causes a different legal implication as the legal terminology of liquidation is principally different than bankruptcy. Therefore, liquidation is not necessarily conducted due to the debtor's bankruptcy as sometimes the asset liquidation yields assets in excess of liabilities. ${ }^{5}$ One is called as insolvent or bankrupt if there is no wealth left to pay off the remaining liabilities.

\footnotetext{
${ }^{3}$ M. Yahya Harahap, 2009, Hukum Perseroan Terbatas, Sinar Grafika, Jakarta, page 556-557. ${ }^{4}$ Sunarmi, 2009, Hukum Kepailitan, Terbitan Pertama, USU Press, Medan, page 20.

${ }^{5}$ Rahayu Hartini, 2009, Penyelesaian Sengketa Kepailitan di Indonesia: Dualisme Kewenangan Pengadilan Niaga \& Lembaga Arbitrase, Edisi Pertama, Cetakan Ke-1, Kencana Prenada Media Group, Jakarta.
} 
Second, a liquidation always implicates to the dissolution of a company whereas bankruptcy does not. Instead, an insolvent company is usually transferred to a new owner, be it the creditor, the curator, or other third parties. Third, a liquidation can occur without a court order whereas a condition of bankruptcy must be proposed and court-determined.

If a company dissolution occurs due to the shareholders' consensus under the consideration of either the expiration date of a company determined by its constitution or a court's revocation order over an bankruptcy status of the company, the liquidator is the only party authorized for conducting the liquidation process. The article 142 paragraph (6) stipulates that the shareholders' powers overdecisions regarding promotion, demotion, temporary suspension, dismissal, authority, liability, and supervision over the board of directors, are applied mutatis mutandis (equally) to the liquidator. As for liquidator, the shareholders' consensus can solely appoint individual or team as the liquidator or liquidation executor to whom the asset management and settlement of the company are obligated. Due to such immense mandate of powers from the shareholders to the liquidator, liquidation is not only a procedure for which the liquidator is authorized but also the company dissolution. This is due to the role of the liquidator as the only representative of shareholders within the liquidation and bankruptcy. Therefore, as the shareholders' consensus can determine the dissolution of the company, so does the liquidator but with a caveat of the shareholders' approval. Unless if the company dissolution is determined by the court order, the liquidator can only execute the procedure under the court's appointment.

The liquidator could be of a single person or multiple individuals resembling a team. The liquidator is chosen by the shareholders of the assortment of employees or managers, or else, a third party such as attorney-at-law, lobbyist, arbitrator, or related experts. Otherwise, the district court can be requested by the company to appoint a liquidator. Therefore, it would be wise of a company if the appointment of a liquidator has been determined beforehand in the article of association.

\subsection{Liquidator's Liablity in the Limited Company Liquidation Process}

The Bankruptcy Act stipulates that the responsibilities of a liquidator are: 1) to announce the dissolution of the company; 2) to execute the settlement over assets through liquidation, and 3) to report the liquidation outcome.

As for the first liability, the announcement of the company's dissolution by the liquidator is stipulated in the article 147 paragraph (1) point a. There are three procedures which the 
liquidator must undergo for the announcement such as 1) the announcement must be directed for the creditors; 2) the announcement must be issued in newspapers or the Official Gazette of the Republic of Indonesia, and 3) the announcement must consist of the legal standing of dissolution, the name, and address of the liquidator, the procedures of creditor's bill collection, and the due date of billing for 30 days maximum starting from the issue date of the dissolution order by either the shareholders or the court.

As for the second liability, the settlement through asset liquidation is stipulated in the article 149 paragraph (1) of the Limited Company Act in which the procedures are: 1) documentation and collection of the company assets (capitals and liabilities); 2) announcement in newspapers or the Official Gazette of Indonesia regarding the distribution plan of liquidated assets to the creditors, 3)the elucidation on the number of liabilities and the payment procedure to the creditors; 4) the distribution of the liquidated assets in excess of liabilities to the shareholders, and; 5) other measures needed in regard to asset settlement.

According to the Elucidation of the Limited Company Act, the "other measures" include an bankruptcy proposal to the court as stipulated in the article 149 paragraph (2), "in case of the liquidator estimates that a company is having liabilities in excess to capitals, the liquidator shall propose bankruptcy of the company, except the law stipulates otherwiseand/or the creditors, whose identities and addresses are known, approve the settlement out of bankruptcy." This elucidation gives the liquidator an authority to propose the bankruptcy of a company as a part of the liquidation process. However, the article 104 paragraph (1) stipulates that the authority of the board of directors to propose company bankruptcy to the commerce court based solely the shareholders' consensus does not apply mutatis mutandis to the liquidator. Therefore, the liquidator does not need the shareholder consensus in order to propose the company bankruptcy to the commerce court. This kind of proposal is called as 'voluntary petition'. However, the liquidator is not legally obligated to sell the debtor's assets as the article 149 paragraph (1) regarding liquidator's responsibilities does not mention anything regarding such practice.

As for the liability of reporting, the article 152 paragraphs (1) and (2) stipulates on who the report is directed to. According to the law, the liquidation report is directed to the shareholders, the court, and the supervising judge. The article 143 paragraph (3) stipulates that the liquidation report must be addressed to the party who issued the dissolution order that is either the shareholders, the court, or the supervising judge. Therefore, if the company dissolution is determined by the shareholders' consensus, the appointment of liquidator must be included as 
well, hence the report is solely directed to the shareholders. The same procedure also applies to the shareholders. However, the liquidation executor that is responsible to the supervising judge is not liquidator but curator instead, thus the reporting liability applies for the curator to the supervising judge who appointed him/her. Moreover, the appointment of the curator as the dissolution executor only occurs, in accordance to the article 149 paragraph (1) of the Limited Company Act, if the involving parties or a state attorney requested the court to dismiss the liquidator and appoint a new one, a curator. The dismissal will be executed if the defendant, the liquidator, has appeared before the court to give testimony.

The liquidation is perhaps an ideal process for the company's shareholders or board of directors who want to terminate or dissolve the company. The liquidation procedures can affect the future affairs of everyone involved or related to the company whenever there is a problem during the liquidation process. If misconduct of liquidation procedure is found, its negative effect will permeate to the lives of parties related to the company.

The article 49 paragraph (1) of the Limited Company Act does not stipulate any mechanism or procedure regarding the sale of company assets by the liquidator. This lack of regulation on the sale of company assets could impede the liquidation process. In other words, the Limited Company Act does not have necessary substances to regulate the practice ofassetselling by the liquidator or in all, the rigid mechanism of asset liquidation. However, if we refer to the definition of liquidation itself, the procedure essentially includes liability settlement by selling company assets which have been assessed by the independent rating agency and auditor which determines the solvability of a company's balance. Furthermore, the process proceeds with the distribution of the liquidation's yield to the creditor in which the liquidator is authorized to manage and regulate the distribution fairly. This indicates the role of a liquidator as not only a mediator between creditor and debtor, but also as the enforcer of law as to the aspect of legal certainty. Here legal certainty is understood as to assure the legality of the whole process of liquidation from the collection, selling, to the distribution of assets.

The article 149 paragraph (1) point e stipulates that the responsibilities of liquidator include "other measures" needed to ensure the settlement process. Therefore, if the liquidator intends to sell company assets as a part of the liquidation process, thus such process is permissible as long as it abides the prevailing regulations. 


\section{Conclusion}

This article contends that the Limited Company Act is insufficient on ensuring the legal certainty of the asset-selling practice by the liquidator. Therefore, in order to ensure such legal certainty, this article suggests the addition of liability to the liquidator. It is the liquidator's liability to verify the creditor's bills and the liquidator's authority to sell company assets. Without such provision, the liquidation process could be hindered in a way of diminishing the liquidator's independence and honesty in performing its duties as stipulated in the article 149 paragraph (1) of the Limited Company Act.

\section{References}

Fuady, Munir, 2012, Hukum Pailit, Citra Aditya Bakti, Bandung.

Harahap, M. Yahya, 2009, Hukum Perseroan Terbatas, Sinar Grafika, Jakarta.

Hartini,Rahayu, 2013, Hukum Kepailitan, Bayu Media, Malang.

, 2009, Penyelesaian Sengketa Kepailitan di Indonesia: Dualisme Kewenangan Pengadilan Niaga \& Lembaga Arbitrase, Edisi Pertama, Cetakan Ke-1, Kencana Prenada Media Group, Jakarta.

Murni. 2009. “Analisis Terhadap Likuidasi Persekutuan Komanditer (CV), Untuk Menjadi Perseroan Terbatas (PT) dalam Perspektif Hukum Ekonomi”. Tesis: Universitas Diponegoro Semarang.

Sinaga, Syamsudin M, 2012. Hukum Kepailitan Indonesia, PT. Tata Nusa, Jakarta.

Sjahdeini, Sutan Remy, 2009. Hukum Kepailitan: Memahami Undang-Undang Nomor 37 Tahun 2004 Tentang Kepailitan dan Penundaan Kewajiban Pembayaran Utang, PT. Pustaka Utama Grafiti, Jakarta.

Subekti, R, R. Tjitrosudibio, 2010, Kamus Hukum, Pradnya Paramita, Jakarta.

Subekti dan R. Tjitrosoedibio, 1978, Kamus Hukum, Pradya Pramita, Jakarta.

Sunarmi, 2009, Hukum Kepailitan, Terbitan Pertama, USU Press, Medan.

Undang-Undang Nomor 37 Tahun2004 tentang Kepailitan dan Penundaan Kewajiban Pembayaran Utang.

Undang-Undang Nomor 40 Tahun 2007 tentang Perseroan Terbatas. 